\title{
Economic Impact of Thermal Insulation of the Building's Envelope
}

\author{
Salloom A. Al-Juboori \\ Professor in Mechanical and systems Engineering \\ (PhD, M.Sc Leeds University, U.K) \\ Engineering Faculty / Muta'h University / Jordan
}

Doi: 10.19044/esj.2018.c4p10 ＵRL:http://dx.doi.org/10.19044/esj.2018.c4p10

\begin{abstract}
Climate change was the beginning of the depletion of fossil fuels, and increasing expansion in investment projects in various sectors of our life, all play a key role in the increasing demand for energy. So energy is considered one of the biggest priorities and challenges facing the world economy due to the lack of conventional energy sources of crude oil and natural gas used in energy generation. The use of thermal insulation materials in building's envelope is one of the ways to reduce energy consumption. Therefore, this study will address the importance of the use of thermal insulation materials in building' envelope to reduce energy loss as a result of heating and cooling conditions. The case sudy was the implementation of thermal insulation on Engineering Faculty building's envelope/ Muta'h University. The thermal loads were calculated for the building, with and without thermal insulation, by using four common different insulation materials which are; Rockwool, foam concert, double-glazing and extended Polystyrene. The selection of these materials depends on availability in the market, cost of implementation and the coefficient of thermal conductivity. The results showed that the polystyrene extended of thickness $10 \mathrm{~cm}$ is the best material for the thermal insulation in comparison of the others. The reduction ratio in thermal transmittance reached up to $76 \%$; while in volume ratio of central heating fuel consumption reached up to $26.7 \%$.
\end{abstract}

Keywords: Thermal Insulation Materials, Thermal Conductivity Coefficient, Building's envelope, and Fuel Consumption

\section{Background}

Energy is considered one of the biggest challenges faced by the most of the world countries. It is a very big challenge due to the fact that the lacks of energy sources and thus relies on imported sources. Energy is necessary for 
the economic and social growth. Large quantities of energy are needed per year due to the nature of the prevailing climate. Oil and its derivatives constitute $95 \%$ of consumed commercial energy in some countries. One of the derivatives of oil is natural gas, which is the best fuel in power generation in terms of lack of damages to the environment. The development and increase in the population in recent years has led to an increase in energy demands. Most of these energy demands are attributed mostly to the heating and cooling processes, at levels that exceed the capacity of the country's economy, rather than being exploited in development projects. This prompts an interest in following the ways and means intended to ration energy consumption (Akacir, etal 2010). These methods use thermal insulation in buildings, including residential buildings, to ration consumption and reduce spent energy on air conditioning in homes, and public buildings. It is necessary to use a material suitable for year-round use and for all weather conditions. In addition, it must be within the composition and design of the ideal buildings insulators, i.e. it is important to not only consider economic restrictions, but also consider factors affecting health, both by reducing acoustic pollution (due to noisy air conditioning devices) or gaseous pollution and other waste products. All these can be accomplished through the rationing of energy consumption, which in turn will reduce the fuel consumption and the production of pollutants. The use of thermal insulation in buildings is very important in the rationalization of the growing consumption of energy. This is reflected economically for individuals in particular, and society in general. Insulation can result in benefit from energy in the various projects development, such as agricultural, industrial, commercial, scientific and cultural fields, as well as the environment and health by reducing noise pollution and the deposition of toxic elements in nature (Duijve 2012).

\section{The Problem of the Study}

Energy has become one of the priorities of the national economy, due to the lack of conventional energy sources of crude oil and natural gas which are used to generate electricity (Jin Kim 2009). The increase in the total consumption of primary energy such as crude oil and natural gas due to population growth is up to $6 \%$ increasing rate per year of electricity consumption. In light of the limited power output depending on local energy sources in Jordan, which constitute about $4 \%$ of the total needs of annual capacity and the rest depends on the import of crude oil and oil derivatives and natural gas, to meet the growing fuel needs which arrived in the growth rate (35\%) annually (Al Shebakat 2006). This study aims to contribute of reducing the loss of energy, as a result of leakage of heat in buildings and facilities across the walls, windows, doors and ceilings from the outside to the inside in summer and vice versa in the winter; this occurs due to the un-insulation of 
the building's envelope. The subject of energy conservation has great importance with the increasing energy consumption in various fields, as well as the human need to use the means of heating and cooling for the terms of comfort throughout the year. Thus, it is important to use thermal insulation materials in buildings to conserve energy and achieve the highest degree of physical health and psychological.

\section{Research Objectives}

The main objectives of the present work are:

(1) Analyzing the economic impact of using thermal insulators of the building's envelope

(2) Calculating the required energy consumption for purposes of heating and cooling, where insulators are used on building's envelope and comparing this with non insulated case for the same building to find out the amount of energy saving.

(3) Studying the maintenance cost of the building's evelope due to the heating.

\section{Research hypothesis} results:

The following hypotheses will be tested during the analysis of the

(1) The first hypothesis: What is the economic impact of the use of thermal insulators on building's

envelope?

(2) The second hypothesis: Is the use of thermal insulators on building's envelope can be considered one of

the most effective construction methods to reduce energy consumption?

\section{The Means of Heat Transfer}

Thermal insulation is used in buildings to reduce heat transfer from inside to outside in winter, and from the outside to the inside in the summer. There are three principles of heat transfer, which are conduction, convection and radiation as shown in figure-1 (Wilson 2013). 


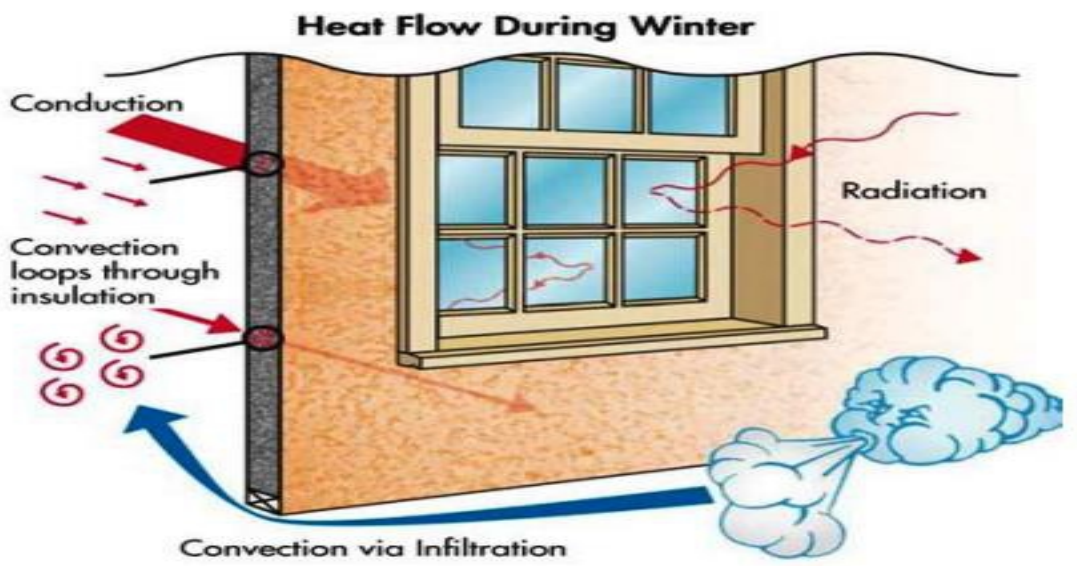

Figure-1 heat transfer from building's envelope (Wilson 2013)

\section{Factors Affecting Thermal Insulation Design}

Thermal evaluation of the buildings objectives are to reduce the heat transfer of the originator, whether the transition from inside to outside in the winter, or vice versa in the summer, and thus secures a comfortable and healthy environment for the occupants of the building and the provision of energy consumed and lower periodic maintenance cost resulting from heat stress of the building (Singh2015).The most important factors that affect the thermal insulation buildings design (Al aaysh 2009) are:

(1) Weather conditions: Weather conditions play an important role in determining the appropriate type of buildings isolation according to the nature climatic conditions.

(2) Types and categories of buildings: Buildings are divided by area and provide them with thermal devices, as well as thermal limitations and exposure to weather factors.

(3) Geographical direction and shape of the structure: The sun is the source of heat which can be used in winter. In addition, the wind speed and the direction, building site and the degree of impact by the sunshine will affect the evaluation and selection of thermal insulation. Also, the construction site of the neighboring buildings, the height, the level of the building if it is several floors play an important role in selection of materials

(4) Conductivity heat: Always preferred that the external elements of the buildings are low heat conductivity as possible (high thermal resistance)

\section{The Environmental Impact of Thermal Insulation Materials}

Thermal insulation impact on the environment is one of the materials manufacture for thermal insulation and the stages used in residential and industrial projects in terms of sustainability and energy saving, heat-resistant, fire resistant, industry, or the formation of some thermal insulation materials 
leads to the emission of environmentally harmful gases. As a result, must focus on the impact of harmful substances to be less to the environment. But the positives of the use of thermal insulation materials will be energy saving of $30 \%$ to $70 \%$ of reducing toxic gases that are released in thermal power plants to produce electricity and rationalize the use of fuel for heating, as well as to create a comfortable atmosphere inside the building in summer and winter. The costs which will provide a result of the rationalization of energy consumption, also the cost of building maintenance (Abu Dayyeh2005)

\section{Thermal Bridges in Structural Elements and Methods of Treatment}

They are considered thermal bridges, or what are called in some references as cold bridges. They are weak because they are neglected in the process of implementation of the thermal insulation in buildings. Thermal bridges leak heat significantly. The wastage of energy, moisture condensation, and mold formation are observed on these parts of the building from the inside. Thus, it is required to avoid thermal bridges in buildings which occur in the following cases (ALaaysh 1990):

(a) The concourse of external walls with floor: When implementing the thermal insulation of walls without floors, the thermal insulation layer must extend a distance of no less than $25 \mathrm{~cm}$ from the level of the floor tiles. In the case that the thermal insulation is extended to the flooring, a distance of up to one meter is needed from where the walls meet with the concrete floor as shown in Figures-2 and 3.

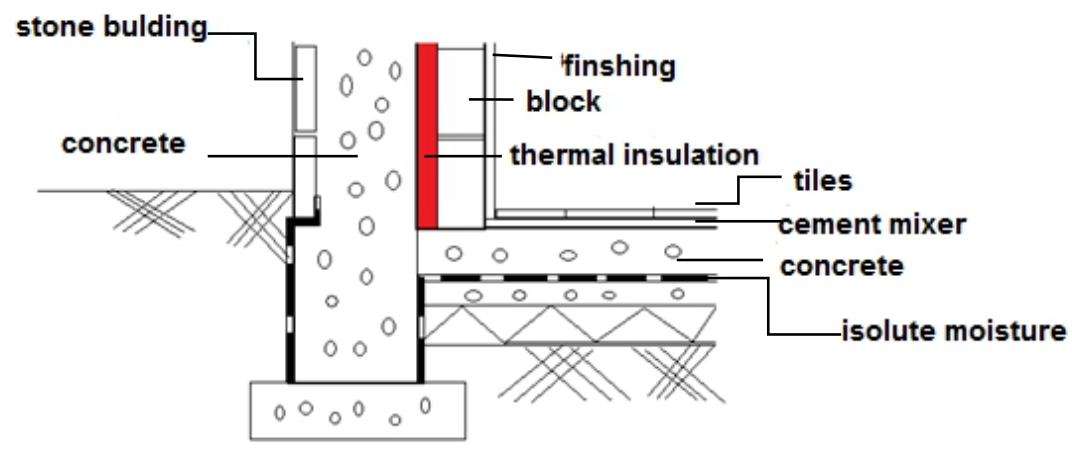

Figure-2 Heat transfer through concourse external walls with floor (Alaaysh1990) 


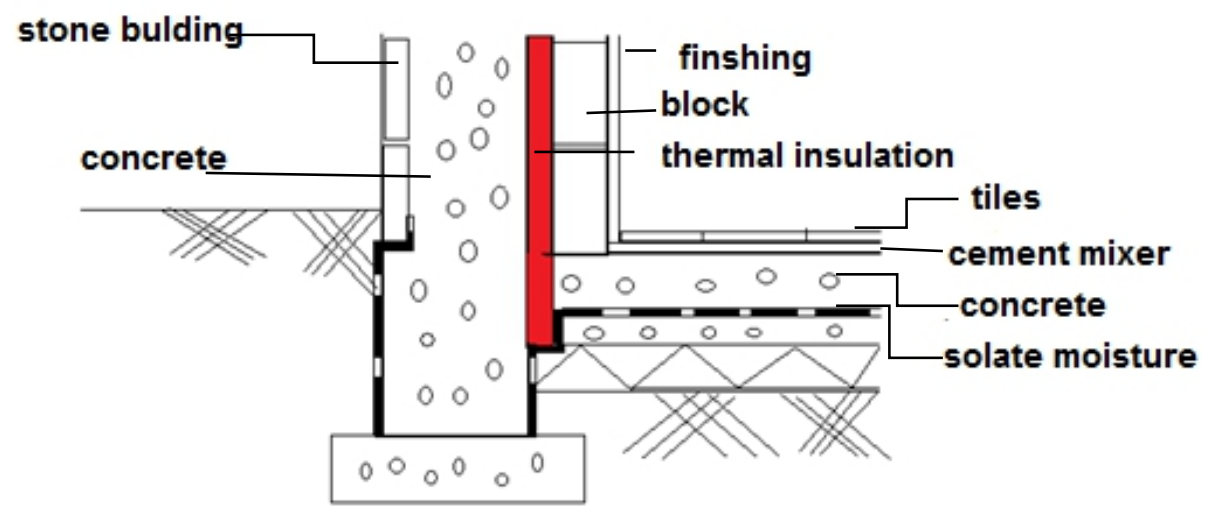

Figure -3 Implementation of the thermal insulation at the concourse of the external walls with floor (Alaaysh, 1990)

(b) The concourse of external walls with ceiling: If thermal insulation is not implemented in a correct manner, these positions constitute a high leakage of heat where it was noted the humidity on the ceiling, corners, or along its edge with the wall. The thermal isolation of these positions requires that the layer of thermal insulator in the walls extends to the lower edge of the roof, until the first row of brick components. This is shown in the figures- 4 and 5. 


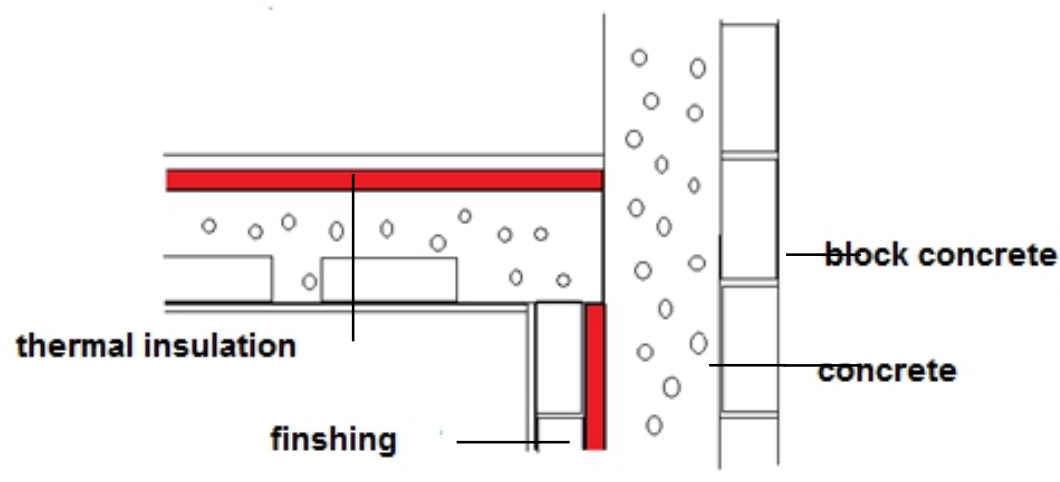

Figure-4 Heat transfer through the concourse the walls with external ceiling (Alaaysh, 1990)

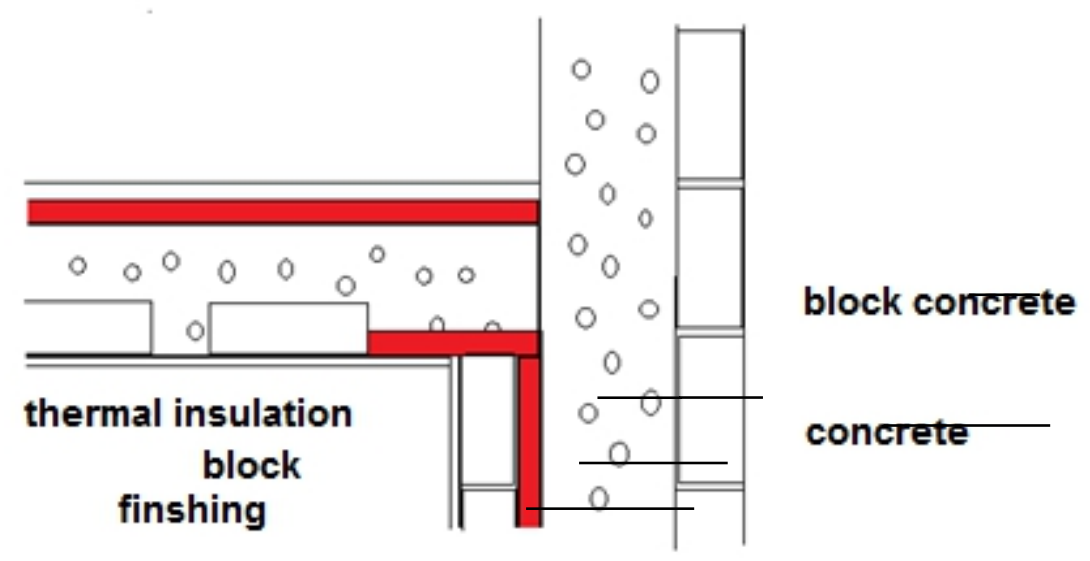

Figure (5) Installation of thermal insulation at the concourse of the walls with external ceiling

(Alaaysh, 1990)

(c) The corners of columns and armed columns in the external walls: These areas are of high leakage of heat if thermal insulation is not implemented properly. The proposed solution to avoid this is by the 
continuation of the thermal insulator at the mentioned points, as shown in Figures-6 and 7.

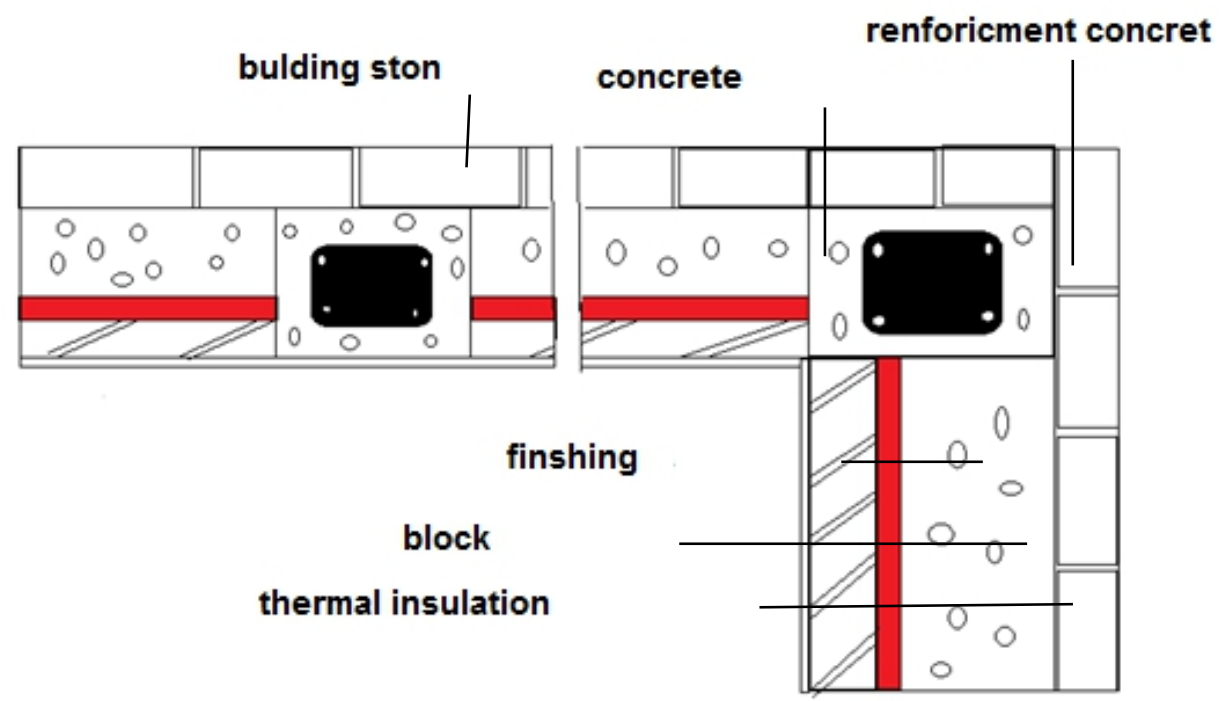

Figure (6) Heat transfer through the columns of corners and armed columns (Alaaysh, 1990)

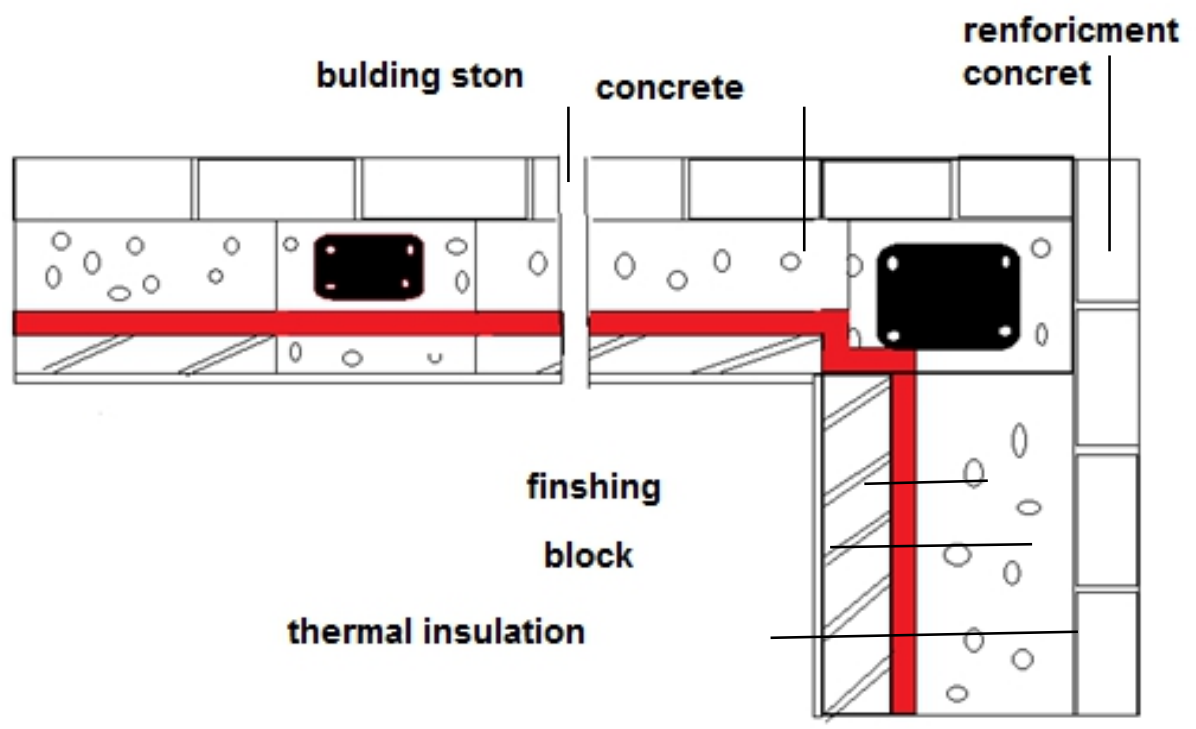

Figure-7 Implementation insulating at columns corners and armed columns (Alaaysh, 1990) 


\section{Case- Study Calculations}

The calculations will outline the importance of materials for thermal insulation in building to reduce the amount of energy consumed and comparing that before and after the building insulated thermally. The case study building is the Engineering Faculty as shown in figure-8 and the calculations will be for the following cases:

Case- 1: The Building without any thermal insulation materials.

Case- 2: The Building with thermal construction insulation materials.

Case-3: The Building with industrial thermal insulation materials.

Case -4: Using Expended Polystyrene material of thickness $(10 \mathrm{~cm})$ for walls, and $(5 \mathrm{~cm})$ for the floors and the ceilings, and using double-glazing for windows and external doors.

For each of the above cases the thermal insulation design will be according to code 2009 (Alaaysh 2009), and calculating the capacity of heating appliances in each case. The case study building consists of three floors; the ground floor includes the area which consists of a courtyard extended to the roof of the building, and coated glass indoor with stairs and 16 class-rooms.

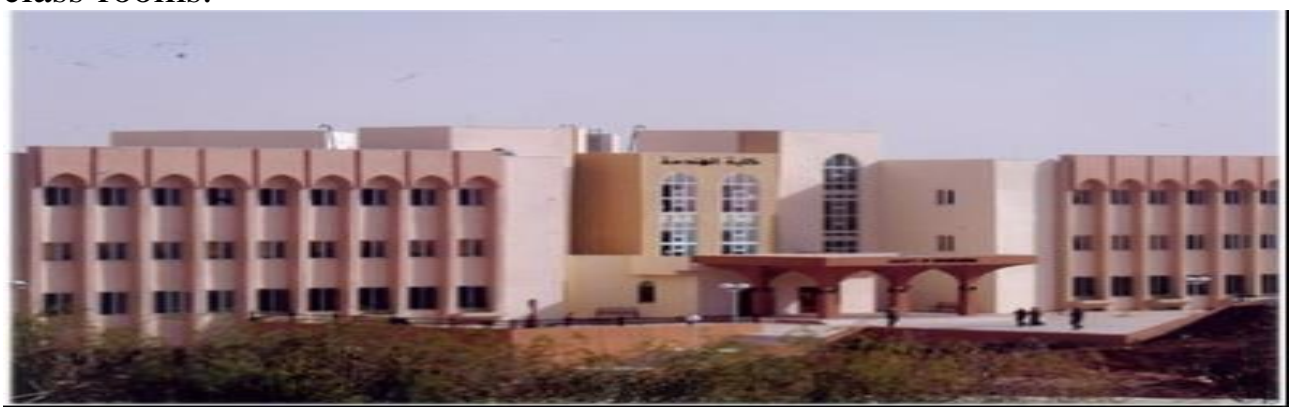

Figure-8 Building of Engineering Faculty

\section{Thermal Loads Calculations}

Thermal loads are calculated by adopting the following data:

- $\quad$ Estimated heated area of the building $=14155.714 \mathrm{~m}^{2}$

- $\quad$ Estimated the external walls area without opining $\left(\mathrm{Ae}_{\mathrm{e}}\right)=5636.56 \mathrm{~m}^{2}$

- $\quad$ Estimated the roof area $=3446.6 \mathrm{~m}^{2}$

- $\quad$ Estimated the opining area $=1514.05 \mathrm{~m}^{2}$

- $\quad$ Estimated the gap area in the calling $=55.950 \mathrm{~m}^{2}$

- $\quad$ The design value of the external temperature of the building in the winter $=0.0 \mathrm{c}^{\mathrm{O}}$

- $\quad$ The design value of the external temperature of the building in the summer $=40 \mathrm{c}^{\mathrm{O}}$

- The design value of the internal temperature of the building in the winter $=18-20 \mathrm{c}^{\mathrm{o}}$ 
- The design value of the internal temperature of the building in the summer $=25 \mathrm{c}^{\mathrm{O}}$

- $\quad$ The design value for the external moisture of the building in the winter: Minimum $=60 \%$, Maximum $=70 \%$, while in summer $\operatorname{minimum}=36 \%$ and $\max .=42 \%$

- The market prices of thermal insulation materials are: $7.9 \mathrm{JD} / \mathrm{m}^{2}$ for the $10 \mathrm{~cm}$ polystyrene boards, $3.59 \mathrm{JD} / \mathrm{m}^{2}$ for the $5 \mathrm{~cm}$ polystyrene boards, 5 $\mathrm{JD} / \mathrm{m}^{2}$ for the $10 \mathrm{~cm}$ Rockwool coil , $2.5 \mathrm{JD} / \mathrm{m}^{2}$ for the $5 \mathrm{~cm}$ Rockwool coil , $5.5 \mathrm{JD} / \mathrm{m}^{2}$ for the $10 \mathrm{~cm}$ foam concert and the double glazing is $17 \mathrm{JD} / \mathrm{m}^{2}$

- $\quad$ The price of diesel fuel $=0.35 \mathrm{JD} / \mathrm{L}$ according to year 2015 market price

- The amount of fuel consumed for five years (2016-2017), which was obtained from the maintenance department as in table-1

Table-1; the fuel consumption of the Faculty of Engineering for 2016- 2017

\begin{tabular}{ccc}
\hline Year & $\begin{array}{c}\text { Amount of fuel } \\
\text { consumed(L/year) }\end{array}$ & $\begin{array}{c}\text { Cost of fuel } \\
\text { consumed } \\
\text { (JD) }\end{array}$ \\
\hline 2013 & 27028 & 9459.8 \\
2014 & 30159 & 10555.65 \\
2015 & 20276 & 7096.6 \\
2016 & 16969 & 5939.15 \\
2017 & 15977 & 5591.95 \\
Total fuel consumption at 5 & 22081.8 & 7728.63 \\
years & & \\
\hline
\end{tabular}
equation:-

To calculate the heat transfer coefficient by using the following $\mathbf{U}=\mathbf{1} / \mathbf{R}_{\mathbf{T}}$

$\mathbf{U}$ : Thermal Transmittance

$\mathbf{R}_{\mathrm{T}}$ : Total Thermal Resistance

$\mathbf{R}_{\mathbf{T}}=\mathbf{R}_{\mathbf{i}}+\mathbf{R}_{\mathbf{c}}+\mathbf{R}_{\mathrm{Si}}+\mathbf{R}_{\mathrm{SO}}$

$\mathbf{R}_{\mathbf{i}}$ : Thermal Resistance of the structural element

$\mathbf{R}_{\mathbf{c}}$ : Cavity Thermal Resistance .

$\mathbf{R}_{\mathrm{Si}}$ : Thermal Resistance of the internal surface .

Rso : Thermal Resistance of the outer surface.

$\mathbf{R}=\mathbf{d} / \mathbf{k}$

$\mathbf{R}$ : Thermal Resistance

d : Layer thickness of structural element.

k : Thermal Conductivity .

To calculate the total heat loads is by using the following equation:

$$
\mathbf{Q}_{\mathrm{T}}=\mathbf{Q}_{\mathbf{C}}+\mathbf{Q}_{\mathbf{V}}-\mathbf{Q}_{\mathbf{i}}
$$

$\mathbf{Q}_{\mathrm{T}}$ : Total Heating Loads 
$Q_{c}$ : Total heating energy which are lost from all external elements of the building and from the heated parts to the non- heating parts in the building $\mathrm{Q}_{\mathrm{c}}$ $=987552.1062 \mathrm{w}$.

Qv : Total energy lost as a result of ventilation or air leakage through the building joints, which will be calculated as follows:

$\mathbf{Q V}_{\mathbf{V}}=\mathbf{0 . 3 3} * \mathbf{N} * \mathbf{V} *\left(\mathbf{T}_{\mathbf{0}}-\mathbf{T}_{\mathbf{i}}\right)$

$\mathbf{V}$ : The size of the space heaters.

$\mathbf{N}$ : The number of times air change per hour ( ach/h), according to Aaaysh, 2009 will be changed in public building from 2 to 3 times

$\mathbf{Q}_{\mathrm{i}}$ : Total gained energy rate which is resulting from thermal sources inside the building such as People, lamps..... act ( $\mathbf{Q}_{\mathbf{i}}$ is assumed to be $150 \mathrm{w} /$ person) . $\mathbf{T}_{\mathrm{i}}=$ The interior temperature of the building $20^{\circ} \mathrm{c}$ exception the ground floor is $10^{\circ} \mathrm{c}$.

$\mathbf{T}_{\mathbf{0}}=$ The outer temperature (assumed $40^{\circ} \mathrm{c}$ )

\section{Samples of Calculations}

Case -1: Without thermal insulation materials:

(1) The calculation of heat loads without any thermal insulation for external walls which consist of hollow concrete block of thickness $25 \mathrm{~cm}$ from interior to exterior face as in figure- 9 and table- 2

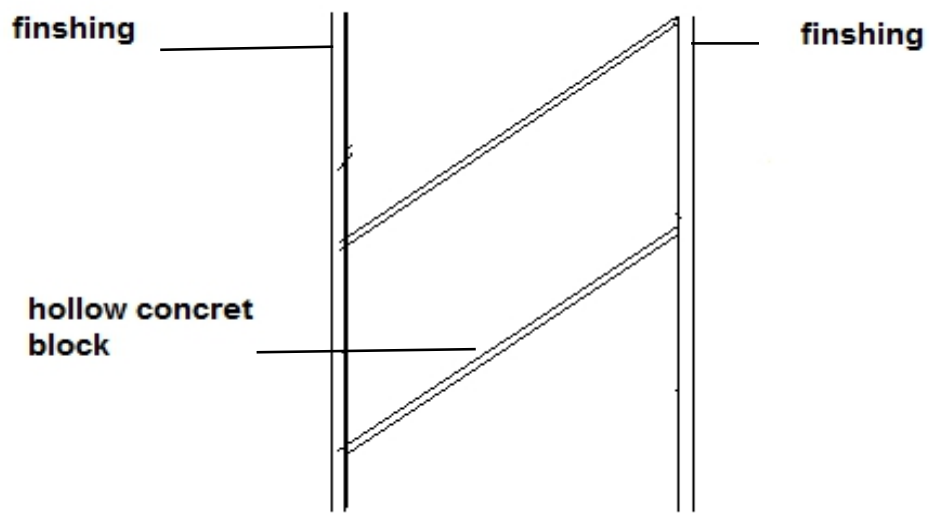

Figure-9; The layers of the walls design without the air vacuum

Table-2; The values of thermal resistance elements of the external walls

\begin{tabular}{cccc}
\hline Elements of construction external walls & $\begin{array}{c}\mathrm{k} \\
\mathrm{w} / \mathrm{m}^{2} . \mathrm{k}\end{array}$ & $\begin{array}{c}\mathrm{d} \\
(\mathrm{m})\end{array}$ & $\begin{array}{c}\mathrm{R}=\mathrm{d} / \mathrm{k} \\
\mathrm{m}^{2} . \mathrm{k} / \mathrm{w}\end{array}$ \\
\hline External finishing & 0.72 & 0.02 & 0.028 \\
Hollow concrete block & 0.49 & 0.25 & 0.51 \\
Internal finishing & 0.72 & 0.02 & 0.028 \\
\hline
\end{tabular}


The calculation of the related elements:

$\begin{array}{ll}\text { - } & \mathrm{R}_{\mathrm{so}}=0.04 \mathrm{~m}^{2} \cdot \mathrm{k} / \mathrm{w} \\ \text { - } & \mathrm{R}_{\mathrm{si}}=0.13 \mathrm{~m}^{2} \cdot \mathrm{k} / \mathrm{w} \\ \text { - } & \mathrm{R}_{\mathrm{T}}=0.739 \mathrm{~m}^{2} \cdot \mathrm{k} / \mathrm{w} \\ \text { - } & \mathrm{U}=1 / 0.739 \mathrm{~m}^{2} \cdot \mathrm{k} / \mathrm{w} \\ & \mathrm{U}=1.353 \mathrm{~W} / \mathrm{m}^{2} \mathrm{k}\end{array}$

(2) The roof consists of a hollow concrete block of thickness $18 \mathrm{~cm}$, concrete layer light-concrete reinforced sloping of thickness $14 \mathrm{~cm}$, finishes with asphalt and filancot as shown in figure-10 and table -3

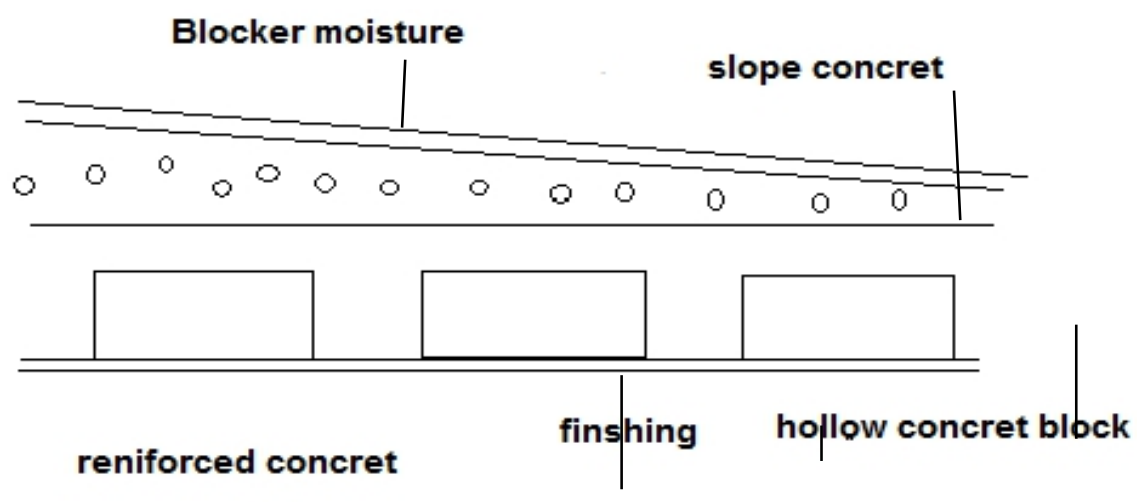

Figure-10; The elements of Roof construction

Table-3; The values of thermal resistance elements of the Roof

\begin{tabular}{cccc}
\hline Elements of Roof & $\begin{array}{c}\mathrm{K} \\
\mathrm{W} / \mathrm{m}^{2} . \mathrm{k}\end{array}$ & $\begin{array}{c}\mathrm{d} \\
\mathrm{m})(\end{array}$ & $\begin{array}{c}\mathrm{R}=\mathrm{d} / \mathrm{k} \\
\mathrm{m}^{2} . \mathrm{k} / \mathrm{W}\end{array}$ \\
\hline External finishing & 0.70 & 0.02 & 0.028 \\
Reinforced concrete & 1.75 & 0.14 & 0.08 \\
Hollow concrete block & 0.95 & 0.18 & 0.189 \\
Internal finishing & 0.72 & 0.02 & 0.028 \\
\hline
\end{tabular}

The calculation of the related elements:

$\mathrm{R}_{\mathrm{si}}=0.1 \mathrm{~m}^{2} . \mathrm{k} / \mathrm{w}$

$\mathrm{R}_{\mathrm{so}}=0.04 \mathrm{~m}^{2} . \mathrm{k} / \mathrm{w}$

$\mathrm{R}_{\mathrm{T}}=0.465 \mathrm{~m}^{2} . \mathrm{k} / \mathrm{w}$

$\mathrm{U}=1 / 0.465=2.151 \mathrm{w} / \mathrm{m}^{2} . \mathrm{k}$ 
(3) The floors consisting of a mixture of grit thickness of $10 \mathrm{~cm}$ - layer Concrete normal sloping thickness of $10 \mathrm{~cm}-$ tiles. As in figure-11 and table $-4$

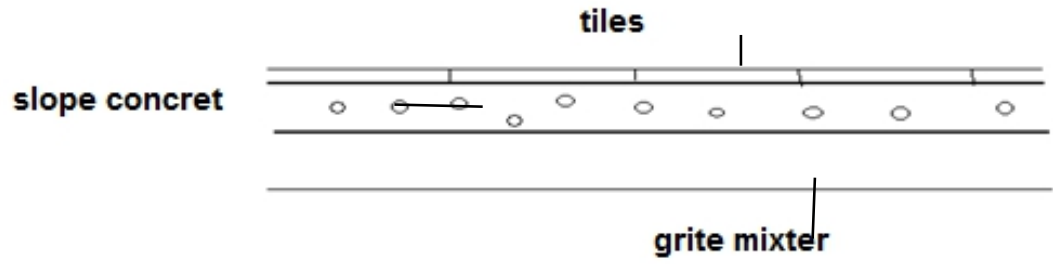

Figure -11; The elements of Ground

Table-4; The values of thermal resistance element it's of the Ground floor

\begin{tabular}{cccc}
\hline Elements of Ground floor & $\begin{array}{c}\mathrm{K} \\
\mathrm{W} / \mathrm{m}^{2} . \mathrm{k}\end{array}$ & $\begin{array}{c}\mathrm{D} \\
\mathrm{m})(\end{array}$ & $\begin{array}{c}\mathrm{R}=\mathrm{d} / \mathrm{k} \\
\mathrm{m}^{2} . \mathrm{k} / \mathrm{W}\end{array}$ \\
\hline Tilles & 0.99 & 0.25 & 0.253 \\
Cément mixé & 0.72 & 0.02 & 0.208 \\
Concrète & 0.56 & 0.1 & 0.178 \\
Grit mixture & 1.5 & 0.1 & 0.067 \\
\hline
\end{tabular}

The calculation of the related elements:

$\mathrm{R}_{\mathrm{si}}=0.17 \mathrm{~m}^{2} . \mathrm{k} / \mathrm{w}$

$\mathrm{R}_{\text {so }}=0.04 \mathrm{~m}^{2} . \mathrm{k} / \mathrm{w}$

$\mathrm{R}_{\mathrm{T}}=0.736 \mathrm{~m}^{2} . \mathrm{k} / \mathrm{w}$

$\mathrm{U}=1 / \mathrm{o} .736=1.359 \mathrm{w} / \mathrm{m}^{2} . \mathrm{k}$

(4) The windows were openings normal single-layer glaze and the external doors are glazed iron, so the calculated elements are :-

$\mathrm{U}_{\text {glasses }}=5.7 \mathrm{w} / \mathrm{m}^{2} . \mathrm{k}$

$\mathrm{U}_{\text {ceiling glasses }}=6.1 \mathrm{w} / \mathrm{m}^{2} . \mathrm{k}$

$\mathbf{U}_{\text {average }}=\operatorname{Sum}\left(\mathbf{A}_{\mathrm{e}} * \mathbf{U}\right) / \mathbf{A}_{\mathbf{T}}$

$\mathrm{U}_{\text {wall }}=5636.56 * 1.359=7660.08 \mathrm{w} / \mathrm{m}^{2} . \mathrm{k}$

$\mathrm{U}_{\text {roof }}=3446.6 * 2.151=7413.64 \mathrm{w} / \mathrm{m}^{2} . \mathrm{k}$

$\mathrm{U}$ ground $=3502.554 * 1.359=4759.97 \mathrm{w} / \mathrm{m}^{2} . \mathrm{k}$

$\mathrm{U}$ glasses $=1514.05 * 5.7=8630.08 \mathrm{w} / \mathrm{m}^{2} . \mathrm{k}$

$\mathrm{U}$ ceiling glasses $=55.950 * 6.1=341.30 \mathrm{w} / \mathrm{m}^{2} . \mathrm{k}$

$\mathrm{U}_{\text {average }}=28805.07 / 14155.714=2.03 \mathrm{w} / \mathrm{m}^{2} . \mathrm{k}$ 
$\mathrm{Q}_{\text {wall }}=1.359 * 5636.56 * 20=153201.7008 \mathrm{w}$

$\mathrm{Q}_{\text {roof }}=2.151 * 3446.60 * 20=148272.732 \mathrm{~W}$

$\mathrm{Q}_{\text {ground }}=1.359 * 3502.55 * 10=47599.6545 \mathrm{w}$

$\mathrm{Q}_{\text {glass }}=5.7 * 1514.05 * 20=172601.7 \mathrm{~W}$

$\mathrm{Q}_{\text {ceiling glass }}=6.1 * 55.95 * 20=6825.9 \mathrm{w}$

$\mathrm{Q}_{\mathrm{T}}=1515903.794 \mathrm{~W}$

(5) Boiler Energy :

The boiler energy will be calculated as follows: $1515903.794 * 0.85$

$($ Conversion Energy (Watts) to the heat emitted $(\mathrm{kcal})=1288518.224 \mathrm{kcal} /$ $\mathrm{h}$

The amount of heat emitted per each thermal radiator $=130 \mathrm{kcal} / \mathrm{h}$

The number of thermal radiators needed for building $=$ $1288518.224 / 130=9912$ units

(6) Calculation of the amount of emitted $\mathrm{CO}_{2}$ :

Total fuel consumption for the five years $(2011-2015)=22081.8$ L/year, for the non-thermal insulated case.

So, the amount of $\mathrm{CO}_{2}$ emitted $=22081.8 \mathrm{~L} * 0.84 \mathrm{~kg} / \mathrm{L}$ (Diesel density in the winter $=0.84 \mathrm{~kg} \backslash \mathrm{L})=18548.712 \mathrm{~kg}$

Where, $\left(175 \mathrm{~g} / 1 \mathrm{~kg}\right.$ is the standard ratios of $\mathrm{CO}_{2}$ emitted from the exhaust of diesel $=18548.712 * 0.175=3246.025 \mathrm{~kg}$

(7) The economic feasibility:

The calculations of consumption cost as follows:

The cost of $($ Boiler + radiators $)=75000+(9912 * 20)=273240 \mathrm{JD}$

The cost of fuel consumption $=22081.8 * 0.35=7728.63 \mathrm{JD}$

So, the total cost $=273240+7728.63=280968.63 \mathrm{JD}$

Case2: Using Industrial Thermal Construction Insulation Materials

(1) External walls consist of hollow concrete block of thickness $15 \mathrm{~cm}$ from the outside and a vacuum air of thickness $5 \mathrm{~cm}$. Block and hollow concrete of thickness $10 \mathrm{~cm}$ from the inside and finishes for interior and exterior face as in Figure-12 and table-5. 


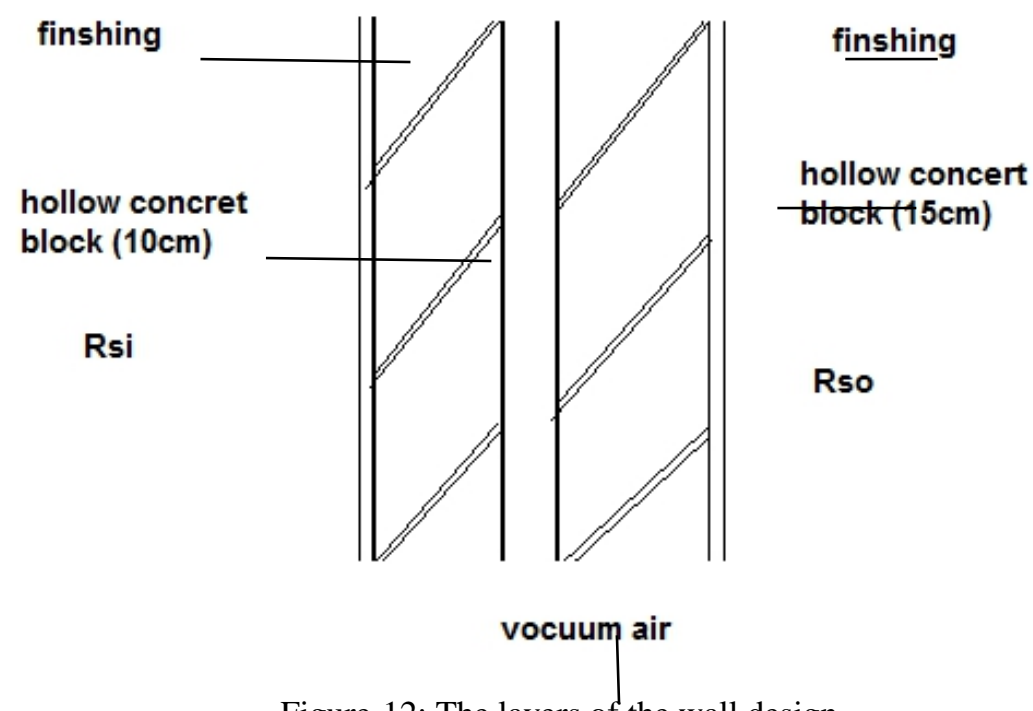

Figure-12; The layers of the wall design

Table-5; The values of thermal resistance elements of the external wall

$\begin{array}{cccc}\text { Elements of } & \mathrm{k} & \mathrm{D} & \mathrm{R}=\mathrm{d} / \mathrm{k} \\ \text { external walls } & \mathrm{w} / \mathrm{m}^{2} \cdot \mathrm{k} & (\mathrm{m}) & \mathrm{m}^{2} \cdot \mathrm{k} / \mathrm{w}\end{array}$

External finishing

0.72

0.20

0.28

Hollow concrete block

0.49

0.15

0.30

Vacuum air

0.49

0.05

0.11

Hollow concert block

0.72

0.1

0.204

Internal finishing

0.02

0.028

The calculations are :

$\mathrm{R}_{\mathrm{so}}=0.04 \mathrm{~m}^{2} \cdot \mathrm{k} / \mathrm{w}$

$\mathrm{R}_{\mathrm{si}}=0.13 \mathrm{~m}^{2} . \mathrm{k} / \mathrm{w}$

$0.846 \mathrm{~m}^{2} . \mathrm{k} / \mathrm{w}=\mathrm{R}_{\mathrm{T}}$

$\mathrm{U}=1 / 0.846$

$\mathrm{U}=1.183 \mathrm{w} / \mathrm{m}^{2} . \mathrm{k}$

(2) the roof consists of a hollow concrete block of thickness $18 \mathrm{~cm}$, light concrete layer - reinforced concrete of thickness $14 \mathrm{~cm}$ - finishes with asphalt and filancot as in figure-13 and table- 6 . 


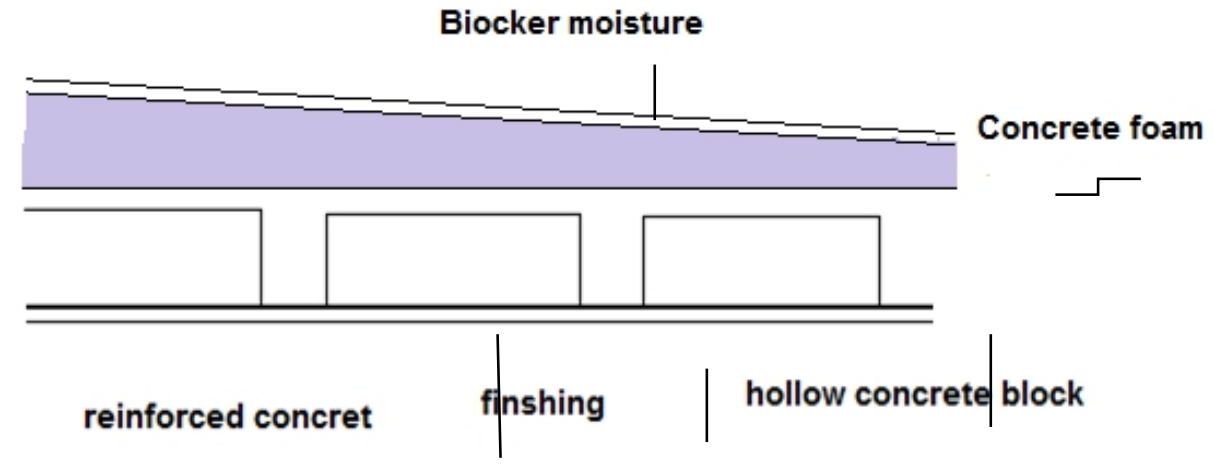

Figure-13; The elements of roof

Table-6; The values of thermal resistance elements of the Roof

\begin{tabular}{cccc}
\hline Elements of construction Roof & $\begin{array}{c}\mathrm{k} \\
\mathrm{w} / \mathrm{m}^{2} . \mathrm{k}\end{array}$ & $\begin{array}{c}\mathrm{d} \\
(\mathrm{m})\end{array}$ & $\begin{array}{c}\mathrm{R}=\mathrm{d} / \mathrm{k} \\
\mathrm{m}^{2} . \mathrm{k} / \mathrm{w}\end{array}$ \\
\hline External finishing & 0.70 & 0.02 & 0.028 \\
Reinforced concrete & 1.75 & 0.14 & 0.08 \\
Concert foam & 0.16 & 0.1 & 0.625 \\
Hollow concrete block & 0.95 & 0.18 & 0.189 \\
Internal finishing & 0.72 & 0.02 & 0.028 \\
\hline
\end{tabular}

The calculations are :

$\mathrm{R}_{\mathrm{si}}=0.1 \mathrm{~m}^{2} \cdot \mathrm{k} / \mathrm{w}$

$\mathrm{R}_{\text {so }}=0.04 \mathrm{~m}^{2} . \mathrm{k} / \mathrm{w}$

$\mathrm{R}_{\mathrm{T}}=1.087 \mathrm{~m}^{2} . \mathrm{k} / \mathrm{w}$

$\mathrm{U}=1 / 0.465=0.919 \mathrm{w} / \mathrm{m}^{2} \cdot \mathrm{k}$

(3) The floors consist of a mixture of grit of thickness $10 \mathrm{~cm}$, concrete layer of thickness $10 \mathrm{~cm}$ and tiles as in figure-14 and table- 7 . 


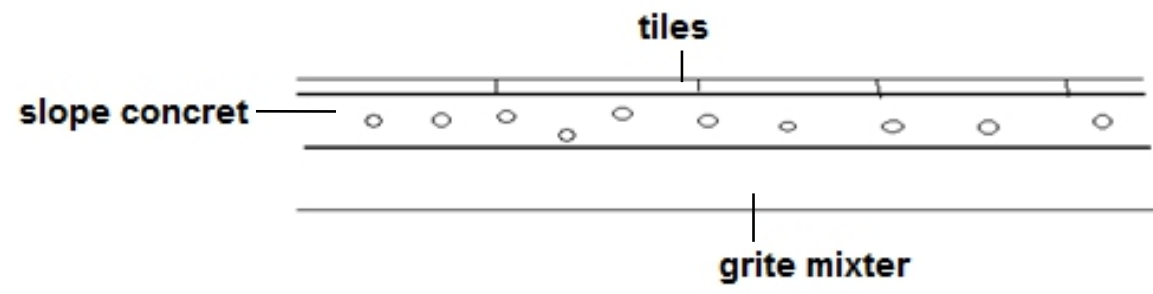

Figure-14; The elements of ground

Table -7; The values of thermal resistance elements of the ground floor

\begin{tabular}{cccc}
\hline Elements of construction Ground floor & $\begin{array}{c}\mathrm{k} \\
\mathrm{w} / \mathrm{m}^{2} . \mathrm{k}\end{array}$ & $\begin{array}{c}\mathrm{D} \\
\mathrm{m})(\end{array}$ & $\begin{array}{c}\mathrm{R}=\mathrm{d} / \mathrm{k} \\
\mathrm{m}^{2} \cdot \mathrm{k} / \mathrm{w}\end{array}$ \\
& & & \\
\hline Tilles & 0.99 & 0.25 & 0.253 \\
Cément mixé & 0.72 & 0.02 & 0.278 \\
Concrète & 0.56 & 0.1 & 0.178 \\
Grit mixture & 1.5 & 0.1 & 0.067
\end{tabular}

The calculations are :

$\mathrm{R}_{\mathrm{si}}=0.17 \mathrm{~m}^{2} \cdot \mathrm{k} / \mathrm{w}$

$\mathrm{R}_{\text {so }}=0.04 \mathrm{~m}^{2} . \mathrm{k} / \mathrm{w}$

$\mathrm{R}_{\mathrm{T}}=0.736 \mathrm{~m}^{2} . \mathrm{k} / \mathrm{w}$

$\mathrm{U}=1 / 0.736=1.359 \mathrm{w} / \mathrm{m}^{2} \cdot \mathrm{k}$

(4) The windows are openings normal with single- glaze layer and The external doors are glazed iron, the calculations are :-

$\mathrm{U}$ glasses $=5.7 \mathrm{w} / \mathrm{m}^{2} . \mathrm{k}$

$\mathrm{U}$ ceiling glasses $=6.1 \mathrm{w} / \mathrm{m}^{2} . \mathrm{k}$

$\mathrm{U}_{\text {average }}=\operatorname{Sum}(\mathrm{A} * \mathrm{U}) / \mathrm{A}_{\mathrm{T}}$

$\mathrm{U}_{\text {wall }}=5636.56 * 1.183=6668.05 \mathrm{w} / \mathrm{m}^{2} . \mathrm{k}$

$\mathrm{U}_{\text {roof }}=3446.6 * 0.919=3167.425 \mathrm{w} / \mathrm{m}^{2} . \mathrm{k}$

$\mathrm{U}_{\text {ground }}=3502.554 * 1.359=4759.9 \quad \mathrm{w} / \mathrm{m}^{2} . \mathrm{k}$

$\mathrm{U}_{\text {glasses }}=1514.05 * 5.7=8630.08 \mathrm{w} / \mathrm{m}^{2} . \mathrm{k}$

$\mathrm{U}_{\text {ceiling glasses }}=55.950 * 6.1=341.30 \mathrm{w} / \mathrm{m}^{2} . \mathrm{k}$

$\mathrm{U}_{\text {average }}=23566.755 / 14155.714=1.665 \mathrm{w} / \mathrm{m}^{2} . \mathrm{K}$

$\mathrm{Q}_{\text {wall }}=1.183 * 5636.56 * 20=133361.009 \mathrm{w}$ 
$\mathrm{Q}_{\text {roof }}=0.919 * 3446.60 * 20=63348.508 \mathrm{w}$

$\mathrm{Q}$ ground $=1.359 * 3502.55 * 10=47599.6545 \mathrm{w}$

$\mathrm{Q}_{\text {glass }}=5.7 * 1514.05 * 20=172601.7 \mathrm{w}$

$\mathrm{Q}_{\text {ceiling glass }}=6.1 * 55.95 * 20=6825.9 \mathrm{~W}$

$\mathrm{Q}_{\mathrm{T}}=1411138.878 \mathrm{~W}$

(5) The Boiler Energy:

The boiler energy will be calculated as follows : $1411138.878 * 0.85$ $\{$ Conversion Energy (watts) to the heat emitted (kcal) $\}=1199468.046 \mathrm{kcal} /$ $\mathrm{h}$

The amount of heat emitted per unit of thermal radiators $=130 \mathrm{kcal} / \mathrm{h}$ So, the number of units of thermal radiators needed for building is : $1199468.046 / 130=9227$ units

(6) Calculation of the amount of emitted $\mathrm{CO}_{2}$ :

The percentages for reducing the amount of values deduced $=6.9 \%$ as shown in table-9 insulating air used, the thickness $(5 \mathrm{~cm})$ only for walls.

Fuel consumption for the five the years (2011-2015) are:

$=22081.8 * 6.9 \%=1523.6442$ L/year. So, $22081.8-1523.6442=20558.1558$ L/year

The amount of emitted $\mathrm{CO}_{2}=20558.211 * 0.84 \mathrm{~kg} / \mathrm{L}$ (Diesel density in the winter $=0.840 \mathrm{~kg} \backslash \mathrm{L}$ )

$=17268.90 \mathrm{~kg}$

The value $175 \mathrm{~g} / 1 \mathrm{~kg}$ is the standard ratios of emitted $\mathrm{CO}_{2}$ of the exhaust of diesel, so $17268.90 * 0.175=3022.05 \mathrm{~kg}$

(7) The economic feasibility of using the industrial construction thermal insulation :

The percentages for reducing the amount of values deduced $=6.9 \%$ as shown in table-9 insulating air used, the thickness $(5 \mathrm{~cm})$ only for walls:

The cost of $($ Boiler + radiators $)=70000+(9227 * 20)=254540 \mathrm{JD}$

Fuel consumption for the five prior years $(2011-2015)=22081.8$ L/year ( table-1)

$=22081.8 * 6.9 \%=1523.6442 \mathrm{~L} / \mathrm{year}$

So, $22081.8-1523.6442=20558.1558 \mathrm{~L} / \mathrm{year}$ and $20558.211 * 0.35=$ 7195.355 JD

Therefore, the total cost $=261735.355 \mathrm{JD}$

\section{Payback Period Calculations:}

The heating system works four months a year from the beginning of December to the end of March . The payback period was calculated in each case and summarized in table-11 and figure-23. 


\section{Discussion of the Results}

The use of thermal insulation materials in buildings construction have a significant economic benefit through the rationalization of energy consumption as well as to reduce the environmental and health pollution by reducing $\mathrm{CO}_{2}$ emitted ratio as a result of reducing fuel consumption. These results are shown in the tables $(8,9,10$ and 11$)$ and are drawn graphically in figures (15 to 24$)$ as follows:

(1) Figure (15) shows the average thermal resistance Average for all cases, it can be seen the followings:

Case- $1: \mathrm{U}$ average $=2.03 \mathrm{w} / \mathrm{m}^{2} . \mathrm{k}$, which is the largest value because there is no use of any material of thermal insulation in all parts of the building.

Case- $2: \mathrm{U}$ average $=1.665 \mathrm{~W} / \mathrm{m}^{2} . \mathrm{k}$, when using vacuum of thickness 5 $\mathrm{cm}$ between the outer wall of thickness $(15 \mathrm{~cm})$ and inter wall of thickness $(10 \mathrm{~cm})$, foam concrete roof, without isolating floors and ceilings. So, $U$ average dropped to $17.98 \%$ as shown in the table-9. The fact that the insulating the antenna cannot be considered good where the thickness $5 \mathrm{~cm}$ with allowing air movement because the air becomes a good conductor of heat transfer; so it should be of thickness no more than $2.5 \mathrm{~cm}$, in order to make the air as insulators.

Case -3: $\mathrm{U}$ average $=0.84 \mathrm{w} / \mathrm{m}^{2} \cdot \mathrm{k}$, when using Rockwool material of thickness $(10 \mathrm{~cm})$ for walls to get to the limit where the standard specifications of Jordan for thermal insulation, in the ceiling using foam concert of thickness $(10 \mathrm{~cm})$, double glazed for the windows and external doors, so, $\mathrm{U}$ average dropped to 59\% as shown in the table (17), the fact that the building is thermally isolated except for flooring where it is considered one of the Rockwool solutions to save energy due to the use of natural available materials, giving the characteristic of high fire resistance of up to $95 \%$ for materials of natural rocks. But it is difficult to be implemented in the ceilings and floors because of its ability to compression, which affects the heat transfer coefficient that requires more than the quantities required to reach the thickness for implementation.

Case 4: $\mathrm{U}$ average $=0.489 \mathrm{~W} / \mathrm{m}^{2} . \mathrm{k}$, when using Expended Polystyrene material of thickness $(10 \mathrm{~cm})$ for walls, and $(5 \mathrm{~cm})$ for the floors and the ceilings, to get to the limit of the standard specifications of Jordan for thermal insulation of using double-glazed for windows and external doors, Average dropped to $76 \%$ as shown in the table-9. When the building is fully isolated and thermal conductivity coefficient (k) of Polystyrene expended is less than coil Rockwool and vacuum air, it is possible to be used in the ceilings and floors due to its ability to resist compression, and that the advantages of polystyrene does not damage rapidly for long-term, also it is characterized by high resistance to chemicals and has a high resistance to moisture because it does not absorb water or water vapor due to its nature of the closed cell 
structure, which also prevents the passage of heat or cold. With regarding to the central heating system, the calculations were for the amount of heating load ( $\left.\mathrm{Q}_{\mathrm{T}}\right)$ for each case of the above four cases to design Boiler Energy Agency, the number of radiators, the amount of fuel consumed per hour, the amount of spent fuel at the five years (2011-2015), the amount of emitted $\mathrm{CO}_{2}$ in all cases as shown in the table- 8 .

(2) figures (16 to 20) and table-9 show the amount of the reduction in heating load $\left(\mathrm{Q}_{\mathrm{T}}\right)$ for each of the four cases as follows:

Case- 1 , the reduction rate is $0.0 \%$, because the non-use of insulations materials.

Case-2, the reduction rate is $6.9 \%$ due to the use of vacuum insulator.

Case-3, the reduction rate is $22.34 \%$ due to the use of Coil Rockwool for insulation.

Case-4, the reduction rate is $26.7 \%$ due to the use of Expended polystyrene for insulation .

(3) shows the cost of boiler and radiators for each case as follows:

It is clear that the cost of boiler and radiators gradually reduced from case- 1 to case- 4 due to the insulation type used in each case, which reduces the heat loads and the thermal conductivity coefficient for each material which are ; vacuum antenna ,coils rock wool, expanded polystyrene, respectively.

(4) figure (22) shows the annual cost of consumed fuel for each case. Also, the annual cost of consumed fuel gradually reduced from case 1 to case 4 due to the type of insulation used in each case, which reduces the heat loads and the thermal conductivity coefficient for each material.

(5) figure (23) shows the total cost of thermal insulation, boiler and radiator for each case:

This figure illustrates that the total cost in case- 4 is the highest followed by the case- 1 , then thecase- 3 , then the case- 2 and the reason is due to the use of thermal insulation or non use and how to insulate the building fully realized from the outside only as in the case-4; or when using polystyrene extender walls, ceilings, floors, and use double glazing for windows and door openings outer or isolated partially as in the case-2. While in case-3 isolated only wall by vacuum air and the use of foam concrete for the roof without isolating floors; where the isolated walls using coils rock wool and foam concrete for the roof and double glazing for windows the door openings as in the case-1.

Compared to the payback period in which the paid-up capital recovers for each of the four cases, which are summarized in table-11 and drawn in figure (24). It is clear that the payback period depends on insulation material type and on working days of the systems. So, the payback period for caselover case- 4 is the best period compared to the other periods. This is because the use of the polystyrene in the wall, roof and ground, due to its availability 
in markets, the thermal conductivity is lower, and appropriate prices. The coil rock wool, on the other hand, is difficult to implement in the roof and the ground due to its flexibility, compression, the absorption of moisture, and the loss of insulation property, as shown in figure (24) for case-1 over case-3.

The role of engineering management in the use of thermal insulation in the building dates back to the ability and flexibility in making the right decision to select the high quality materials for thermal insulation and their suitability depending on the quality, price, market availability, ease of implementation, and their characteristics in terms of size and weight. Also, to reduce costs and time in the case of the use of thermal insulation dependence on choosing the right thermal insulation; so that the payback period amounts added to the cost of implementing the building to be within the allowed range, which is reflected on the economic side, through the provision of energy consumed?

Table- 8 Parameters Calculations Summary of the Sudied Cases $(1,2,3,4)$

\begin{tabular}{|c|c|c|c|c|}
\hline Values deduced & Case 1 & Case 2 & Case 3 & Case 4 \\
\hline $\mathrm{U}_{\text {wall }}$ & 1.539 & 1.183 & 0,309 & 0.265 \\
\hline $\mathrm{U}_{\text {roof }}$ & 2.151 & 0.919 & 0.919 & 0.505 \\
\hline $\mathrm{U}_{\text {ground }}$ & 1.359 & 1.359 & 1.359 & 0.418 \\
\hline $\mathrm{U}_{\text {glass }}$ & 5.7 & 5.7 & 1.4 & 1.4 \\
\hline $\mathrm{U}_{\text {ceiling glass }}$ & 6.1 & 6.1 & 1.6 & 1.6 \\
\hline $\mathrm{U}_{\text {average }}$ & 2.03 & 1.665 & 0.840 & 0.489 \\
\hline $\begin{array}{l}\text { heating Load Q: } \\
\text { (W) }\end{array}$ & 1515903.794 & 1411138.878 & 1177703.71 & 1111246.693 \\
\hline $\begin{array}{l}\text { Boiler Energy } \\
\quad(\mathrm{kcal} / \mathrm{hr})\end{array}$ & 1288518.224 & 1199468.046 & 1001048.158 & 944559.689 \\
\hline $\begin{array}{l}\text { Fuel consumption } \\
\text { for the } 5 \text { years } \\
\text { (2011-2015) } \\
\text { (L/year) } \\
\text { Number of }\end{array}$ & 22081.8 & 20558.211 & 17148.726 & 16185.96 \\
\hline $\begin{array}{l}\text { sections of thermal } \\
\text { radiators needed } \\
\text { for building }\end{array}$ & 9912 & 9227 & 7701 & 7266 \\
\hline $\mathrm{CO}_{2}$ emitted $(\mathrm{kg})$ & 3246.025 & 2820.795 & 2520.863 & 2379.336 \\
\hline
\end{tabular}


Table-9; Parameters Percentages Summary of the Cases $(1,2,3,4)$

\begin{tabular}{ccccc}
\hline Value & Case 1 & Case 2 & Case 3 & Case 4 \\
\hline $\mathrm{U}_{\text {value }}$ & $0.0 \%$ & $17.98 \%$ & $59 \%$ & $76 \%$ \\
$\begin{array}{c}\text { Heating Load Q: } \\
\text { (w) }\end{array}$ & $0.0 \%$ & $6.9 \%$ & $22.34 \%$ & $26.7 \%$ \\
$\begin{array}{c}\text { Boiler Energy } \\
\text { (kcal) }\end{array}$ & $0.0 \%$ & $6.9 \%$ & $22.34 \%$ & $26.7 \%$ \\
$\begin{array}{c}\text { The amount of fuel } \\
\text { (L/hr) } \\
\text { Number of sections } \\
\text { of } \\
\text { thermal }\end{array}$ & $0.0 \%$ & $6.9 \%$ & $22.34 \%$ & $26.7 \%$ \\
$\begin{array}{c}\text { radiators needed } \\
\text { for building }\end{array}$ & $0.0 \%$ & $6.9 \%$ & $22.34 \%$ & $26.7 \%$ \\
CO 2 & $6.9 \%$ & $2.34 \%$ & $26.7 \%$ \\
\hline
\end{tabular}

Table -10; Costs Summary of all Cases $(1,2,3,4)$

\begin{tabular}{ccccc}
\hline Case study & $\begin{array}{c}\text { The cost of } \\
\text { boiler }+ \\
\text { Radiator } \\
\text { (JD) }\end{array}$ & $\begin{array}{c}\text { The cost } \\
\text { thermal } \\
\text { insulation (JD) }\end{array}$ & $\begin{array}{c}\text { The cost of } \\
\text { Consumer fuel } \\
\text { annually } \\
\text { (JD) }\end{array}$ & $\begin{array}{c}\text { Total Costs } \\
\text { (JD }\end{array}$ \\
\hline Case 1 & 273240 & 0.0 & 7728.63 & 273240 \\
Case 2 & 254540 & 0.0 & 7195.355 & 254540 \\
Case 3 & 204020 & 64409.1 & 6002.054 & 268429.1 \\
Case 4 & 190300 & 89247.967 & 5665.086 & 279547.967
\end{tabular}


Table-1; Summary of the Payback Period Costs of all Cases $(1,2,3,4)$

\begin{tabular}{cccc}
\hline Cases & $\begin{array}{c}\text { The Payback } \\
\text { Period } \\
\text { calculations } \\
\text { (year) }\end{array}$ & $\begin{array}{c}\text { The Payback } \\
\text { Period } \\
\text { calculations } \\
\text { (month) }\end{array}$ & $\begin{array}{c}\text { The Payback Period costs for } \\
\text { heating system works four } \\
\text { months a year from the } \\
\text { beginning of December to the } \\
\text { end of March } \\
\text { (year) }\end{array}$ \\
\hline 1 over 4 & 3 & 36 & 9 \\
1 over 3 & 2.7 & 32.4 & 8.1 \\
1 over 2 & 35 & 420 & 105 \\
2 over 3 & 11.6 & 139 & 34.8 \\
2 over 4 & 16.3 & 196 & 84.9
\end{tabular}

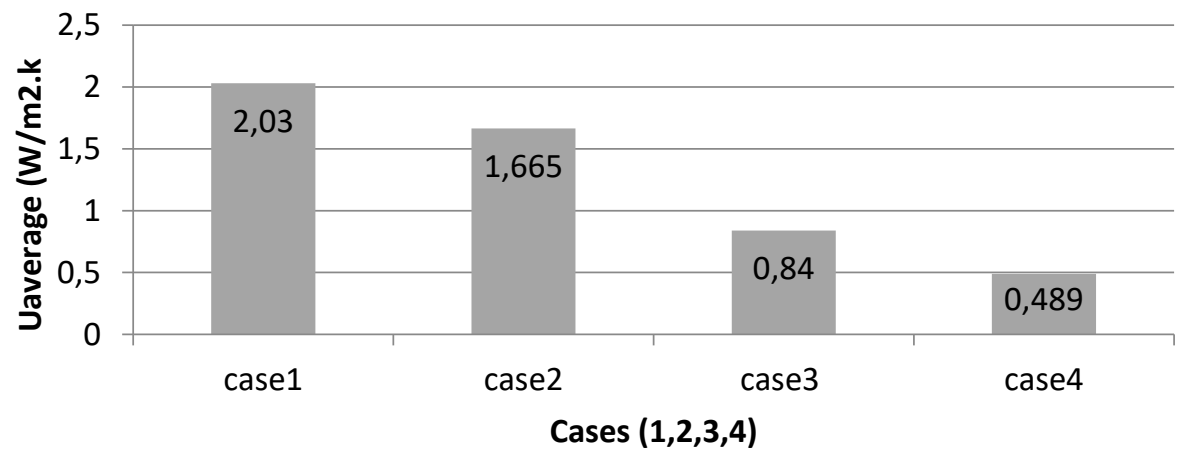

Figure-15; Thermal Transmittance $\mathrm{A}_{\text {verage }}\left(\mathrm{W} / \mathrm{m}^{2} . \mathrm{k}\right)$ for Each Case

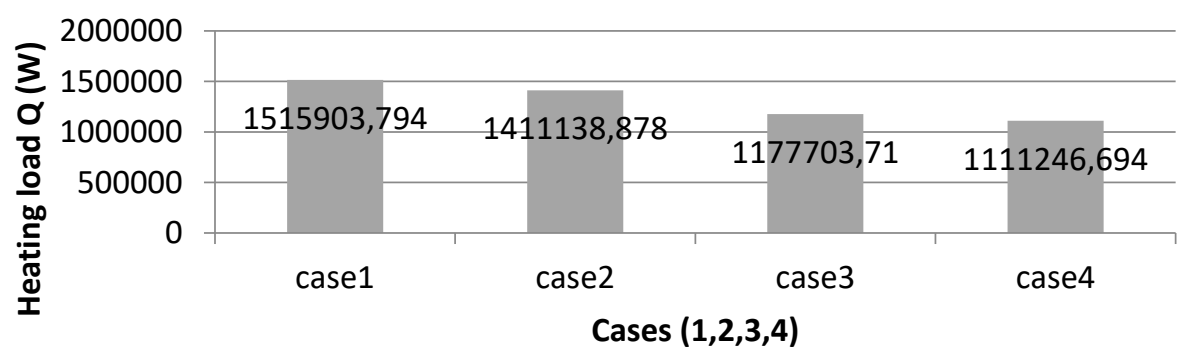

Figure -16; Total heating loads $\left(\mathrm{Q}_{\mathrm{T}}\right)$ for each case study 


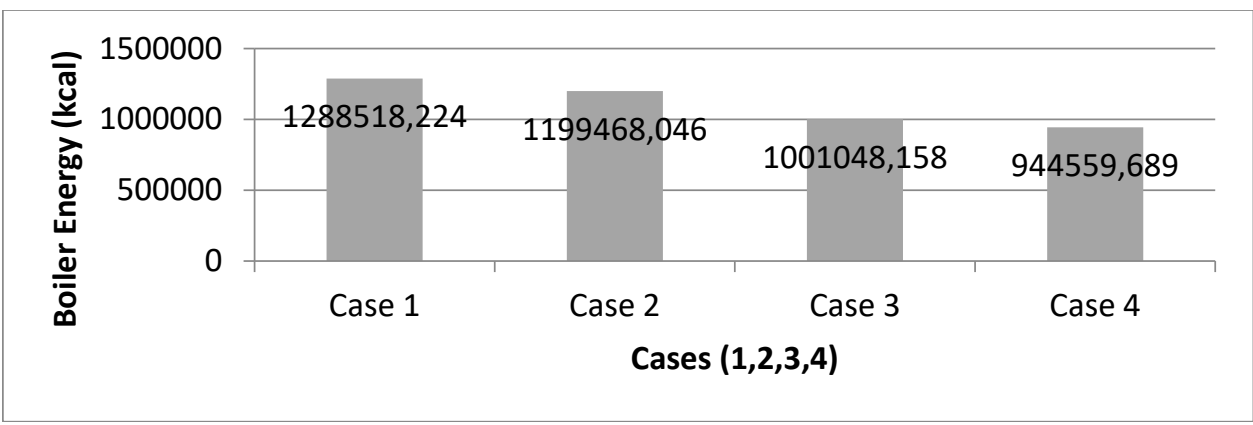

Figure -17; Boiler Energy (kcal/h) for each case

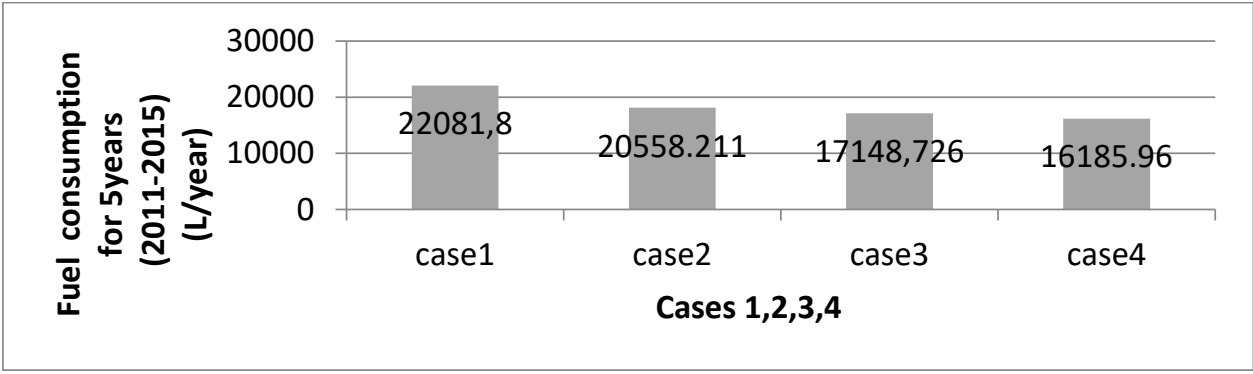

Figure -18; Fuel consumption for 5 years (2011-2015) L/year for each case

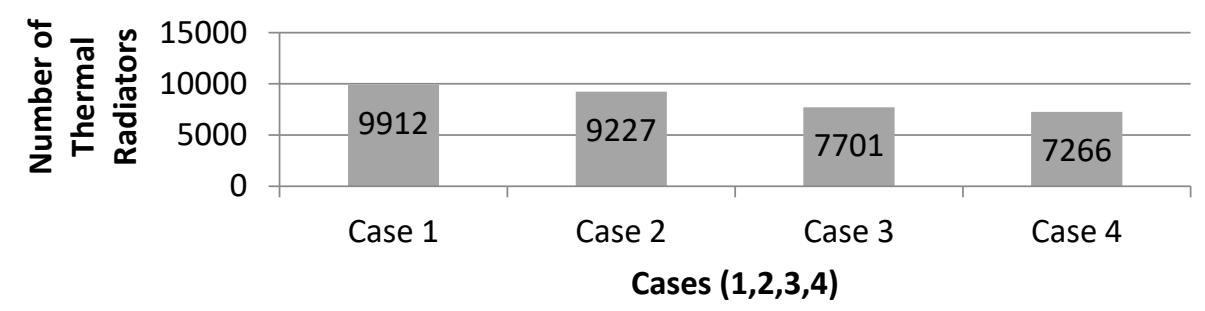

Figure -19; Numbers of Thermal Radiators needed for Building in each case

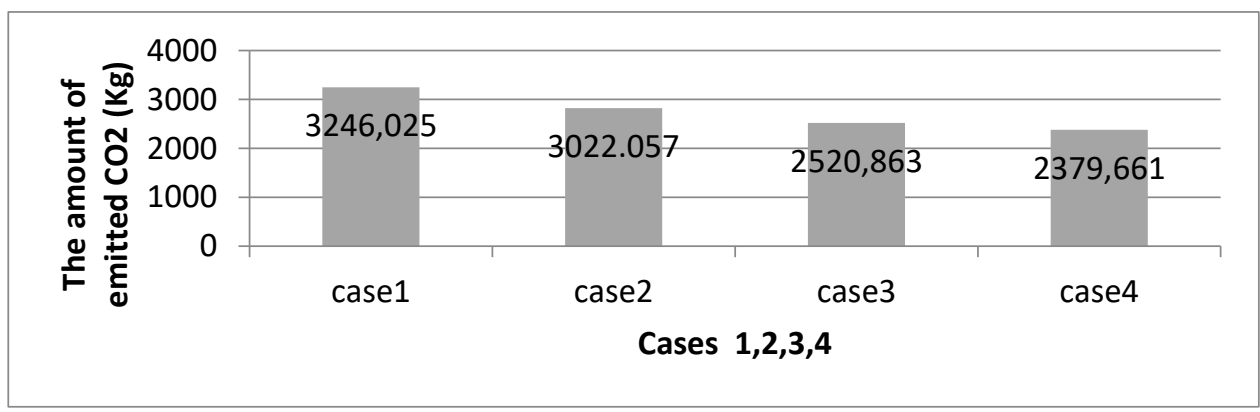

Figure-20; The amount of emitted $\mathrm{CO} 2(\mathrm{~kg})$ for each case 


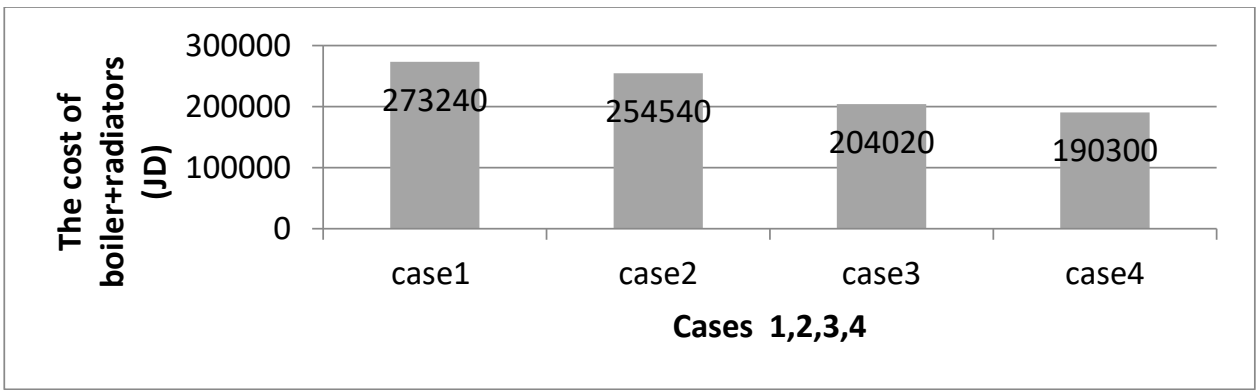

Figure -21; The cost of boiler and radiators (JD)

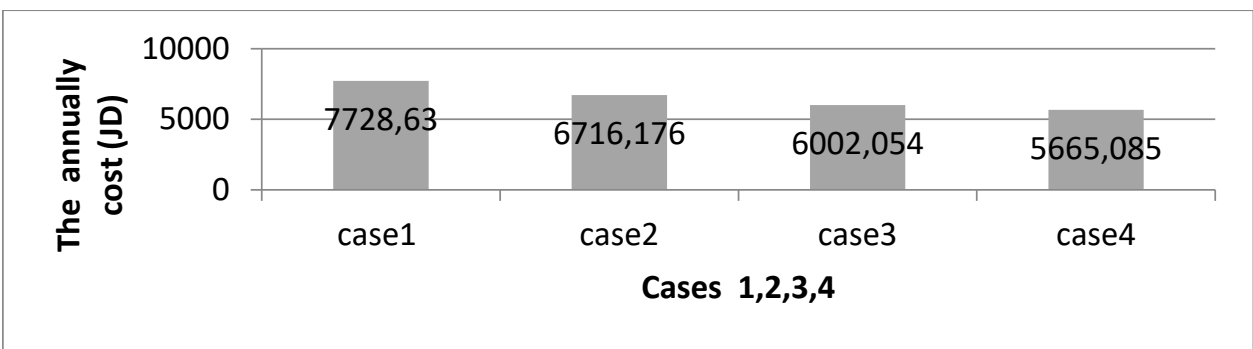

Figuer-22; The annual cost of the consumed fuel (JD)

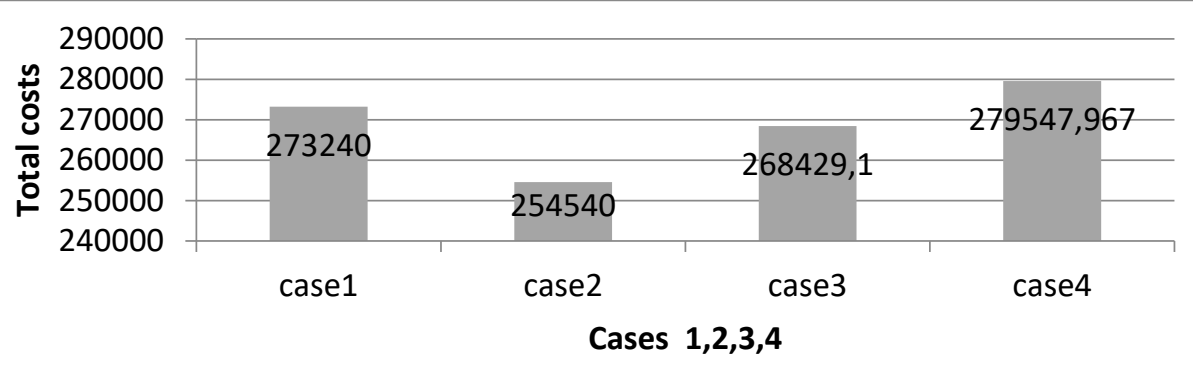

Figure -23; Total Costs of thermal insulation, boiler and radiators (JD)

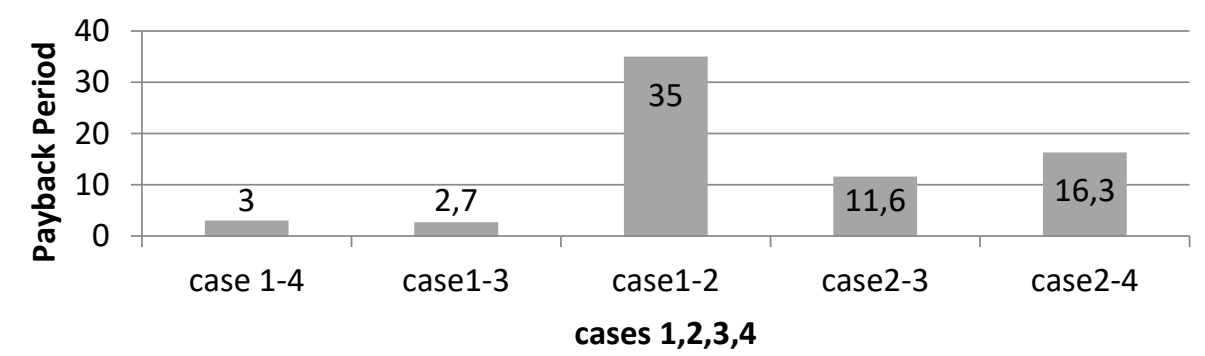

Figure-24; Payback period Costs for all cases 


\section{Conclusion}

From the above results the following main points can be drawn:-

(1) The use of extended polystyrene, double glazing for windows and external opening as thermal insulation of building leads to reduction in thermal transmission (U) to about (76\%), which is the highest among the four studied cases of insulation materials.

(2) The reduction in fuel consumption is the highest by using extended polystyrene which is about $(26.7 \%)$, while the lowest in case with non insulation materials.

(3) Using an extended polyester of thickness $10 \mathrm{~cm}$ in walls resulted in lower fuel consumption and payback period.

(4) When using the extended polyester in all parts of building's envelope with double glazing windows and doors, the total cost of consumed fuel became the lowest value to about (5767.876 JD) in comparison with the other cases.

(5) The pollution is reduced when using good thermal insulation (polystyrene extended) and the lowest value of the emission of $\mathrm{CO} 2$ reaching a ratio to $26.7 \%$ in comparison with other insulations. The highest ratio of emitted $\mathrm{CO} 2$ is in case- 1 without insulator (i.e. $0.0 \%$ ).

(6)The use of coil rock wool in the ceilings, walls and floors showed the woerst due to the difficulty of implementation, its flexibility, the absorption of moisture, loss of its insulation property and compression in walls.

(7)The thermal insulation through the work of a vacuum air between the wall of thicknesses $5 \mathrm{~cm}$ unavailing because the air becomes a good conductor when it moves.

(8) The non-use of thermal insulation in building's envelope causes a high energy lost, also leads to the short life of the building, an increase in the burden cost of maintenance of the building' envelope and replacing appliances.

\section{References:}

1. Aktacir M, Buyukalaca $M$ and Yilma T, 2010 " A case study for influence of building thermal insulation on cooling load and airconditioning system in the hot and humid regions" Contents lists available at Science Direct, Turkey.

2. Duijve M, 2012 " Comparative assessment of insulating materials on technical, environmental and health aspects for application in building renovation to the Passive house level" Energy Science, Utrecht University.

3. Jin Kim J and Woo Moon J, 2009 "Impact Of Insulation On Building Energy Consumption" Eleventh International IBPSA Conference, University of Michigan, USA. 
4. LEWIS C, 1986 "Thermal Insulation from Wood for Buildings: Effects of Moisture and Its Control" Forest Products Laboratory 1 Forest Service U.S. Department of Agriculture.

5. Lingnell W, 2011 "An Introduction to Insulating Glass" IGMA.

6. McCrea A, 2011 "Insulating Your House a Day Guide" The Cordwood Press Ltd, Rams bury, Marlborough, Wilshire, SN82HR.Midrand.

7. Newton G, Roy A and Solomon A, 2014 " Investigation of the Thermal Insulation Properties of Selected Ceiling Materials used in Makurdi Metropolis (Benue State-Nigeria)" American Journal of Engineering Research, Nigeria.

8. Palumbo M; Navarro A; Avellaneda J; and Lacasta A, 2014 " Characterization of thermal insulation materials developed with crop wastes and natural binders, Barcelona School of Building Construction" University of Politècnica de Catalunya,Barcelona, Spain, EscolaTècnica Superior d'Arquitectura del Vallès, University of Politècnica de Cataluña, Sant Cugat del Vallès, Spain.

9. Singh G, 1960 " Building Construction and Materials" Print Media Company, Delhi

10. Wilson A, 2013 " Insulation Choices what you need to know about performance, cost, health and environmental considerations " Green Building, Inc

11. Abu dayyeh A. 2001 " Dialogues about moisture and musty in buildings" National library, Jordan

12. Abu dayyeh A. 2005 " Dialogues about moisture and musty in buildings" Dar flashier, Jordan

13. Aldahook E., 2008 "Heating Systems" Dar alnashier and publishing, Jordan

14. Alshebakat G, 2006 "Energy in Jordan" national Statically Office, Jordan

15. Alaaysh A, 2001 " Polystyrene in thermal insulation" Energy research center, Jordan

16. Alaaysh A, 2009 " thermal insulation codes" buildings research center, Jordan 